\title{
Glomerular size- and charge selectivity in Type 2 (non-insulin-dependent) diabetic patients with diabetic nephropathy
}

\author{
M.-A. Gall, P. Rossing, A. Kofoed-Enevoldsen, F. S. Nielsen, H.-H. Parving \\ Steno Diabetes Center, Gentofte, Denmark
}

Summary In an attempt to evaluate the mechanisms of proteinuria in diabetic kidney disease, we measured the renal clearances of albumin, total IgG, and IgG4 in 20 male Type 2 (non-insulin-dependent) diabetic patients with diabetic glomerulosclerosis (biopsy proven), in 10 male Type 2 diabetic patients without nephropathy (urinary albumin excretion rate $\leq 30 \mathrm{mg} / 24 \mathrm{~h}$ ), and in 10 healthy male subjects. The fractional clearance of albumin was increased in patients with nephropathy: 659 (42-4355) $\cdot 10^{-6}$ (median (range)), compared to 2.6 $(0.2-14.2) \cdot 10^{-6}$ in patients without nephropathy, and $2.3(0.4-4.2) \cdot 10^{-6}$ in healthy subjects. The fractional clearance of total IgG (neutral) and of IgG4 (anionic) was 40-50 times higher in patients with nephropathy compared to the two other groups. The IgG/IgG4 selectivity index was not significantly different in the three groups, being: $1.12(0.06-5.65), 1.16(0.45-3.72)$ and $1.35(0.65-3.34)$ in patients with nephropathy, patients without nephropathy, and healthy subjects, respectively. The IgG/albumin selectivity index was decreased in patients with nephropathy: $0.27(0.01-1.26)$ compared to $1.29(0.07-2.67)(p<0.05)$ and $1.23(0.76-7.84)$ $(p<0.001)$ in patients without nephropathy and healthy subjects, respectively. No significant change in IgG/albumin selectivity index was observed between patients without nephropathy and healthy subjects. The systolic blood pressure was elevated in the patients with nephropathy: $164 \pm 21 \mathrm{~mm} \mathrm{Hg}$ (mean \pm SD) compared to patients without nephropathy: $145 \pm 20 \mathrm{~mm}$ $\mathrm{Hg}(p<0.05)$ and to healthy subjects: $133 \pm 19 \mathrm{~mm} \mathrm{Hg}$ $(p<0.005)$. The diastolic blood pressure was higher in patients with and without nephropathy: $92 \pm 7$ vs $90 \pm 10 \mathrm{~mm} \mathrm{Hg}$ compared to $79 \pm 8 \mathrm{~mm} \mathrm{Hg}(p<0.005)$ in healthy subjects. Our cross-sectional study suggests that impaired barrier size selectivity, probably due to an increase in large pore area ("shunt pathway") in the glomerular capillary wall and systemic hypertension are the major pathogenic mechanisms of proteinuria in Type 2 diabetic patients with diabetic nephropathy. [Diabetologia (1994) 37:195-201]

Key words Type 2 (non-insulin-dependent) diabetes mellitus, diabetic nephropathy, IgG, IgG4, IgG/albumin selectivity index, $\mathrm{IgG} / \mathrm{IgG} 4$ selectivity index.
Proteinuria is the first clinical event in the development of diabetic nephropathy in all diabetic patients whether Type 1 (insulin-dependent) or Type 2 (non-insulin-dependent) [1]. Though the pathogenesis of proteinuria in diabetes has not yet been fully elucidated, it is now widely accepted that there are three main factors in-

Received: 7 June 1993

and in revised form: 25 August 1993

Corresponding author: Dr. M.-A. Gall, Steno Diabetes Center Niels Steensens Vej 2, DK-2820 Gentofte, Denmark volved: haemodynamic forces [2,3], and the size- and charge-selective properties of the glomerular capillary filtration barrier [4-7].

Various approaches have been used to explore protein charge selectivity impairment in diabetes: parallel evaluation of $\mathrm{IgG}$ and albumin excretion $[6,8]$, assessment of possible changes in the isoelectric point of different species of albumin or IgG's excreted in the urine [5], and differential excretion of IgG subclasses with different ionic charges [6, 7]. Previous studies of the size- and charge-selectivity properties of the glomerular basement membrane have almost exclusively dealt with Type 1 diabetic patients [4-7]. In an attempt to 
Table 1. Clinical characteristics of Type 2 diabetic patients with and without diabetic nephropathy and of healthy subjects

\begin{tabular}{|c|c|c|c|c|}
\hline & $\begin{array}{l}\text { Type } 2 \text { with nephro- } \\
\text { pathy } \\
(n=20)\end{array}$ & $\begin{array}{l}\text { Type } 2 \text { without } \\
\text { nephropathy } \\
(n=10)\end{array}$ & $\begin{array}{l}\text { Healthy subjects } \\
(n=10)\end{array}$ & $p$-value \\
\hline $\begin{array}{l}\text { Age }^{\mathrm{a}} \\
\text { (years) }\end{array}$ & $55 \pm 9$ & $53 \pm 7$ & $54 \pm 10$ & NS \\
\hline $\begin{array}{l}\text { Known duration of diabetes }{ }^{a} \\
\text { (years) }\end{array}$ & $11 \pm 7$ & $8 \pm 5$ & - & NS \\
\hline $\begin{array}{l}\text { Urinary albumin excretion rate } \\
(\mathrm{mg} / 24 \mathrm{~h})\end{array}$ & $\begin{array}{l}1688 \\
(418-7886)\end{array}$ & $\begin{array}{l}14 \\
(4-29)\end{array}$ & - & \\
\hline $\begin{array}{l}\text { Retinopathy }(n) \\
\text { (nil/simple/proliferative) }\end{array}$ & $9 / 6 / 5$ & $4 / 6 / 0$ & - & NS \\
\hline $\begin{array}{l}\text { Body mass index } \\
\left(\mathrm{kg} / \mathrm{m}^{2}\right)\end{array}$ & $30.4 \pm 5.0$ & $30.8 \pm 3.0$ & $24.1 \pm 3.1$ & $<0.005^{\mathrm{c} . \mathrm{d}}$ \\
\hline $\begin{array}{l}\text { Antidiabetic treatment }(n) \\
\text { (diet/oral hypoglycaemic agent/insulin) }\end{array}$ & $2 / 11 / 7$ & $3 / 5 / 2$ & - & NS \\
\hline $\begin{array}{l}\text { Haemoglobin } A_{1 c}^{a} \\
(\%)\end{array}$ & $9.2 \pm 2.0$ & $9.5 \pm 2.1$ & $5.3 \pm 0.2$ & $<0.005^{\mathrm{c}, \mathrm{d}}$ \\
\hline
\end{tabular}

${ }^{\mathrm{a}}$ Mean $\pm \mathrm{SD},{ }^{\mathrm{b}}$ median (range).

'Diabetic patients with nephropathy vs healthy subjects, " diabetic patients without nephropathy vs healthy subjects

elucidate the mechanisms of proteinuria in Type 2 diabetes, we studied the renal clearance of albumin, total IgG and IgG4 in patients with biopsy proven diabetic glomerulosclerosis.

\section{Subjects and methods}

\section{Subjects}

In a recent cross-sectional study of all (224 males and 139 women) Type 2 diabetic patients under 66 years old attending Hvidöre Hospital we identified 50 patients ( 7 women) with persistent albuminuria ( $\geq 300 \mathrm{mg} / 24 \mathrm{~h}$ ( $\geq 200 \mu \mathrm{g} / \mathrm{min}$ )) [9]. Persistent albuminuria was defined as urinary albumin excretion $300 \mathrm{mg} / 24 \mathrm{~h}$ or more in at least three consecutive, non-ketotic 24-h urine samples. Renal biopsies were obtained from all albuminuric subjects in whom contraindications were not present. The total biopsy series, comprising 35 cases, is described in detail elsewhere [10]. The renal biopsy revealed diffuse and/or nodular diabetic glomerulosclerosis with no other lesions in 27 patients ( 1 woman), while the remaining 8 patients had a variety of nondiabetic glomerulopathies. The 27 patients with biopsy proven diabetic glomerulosclerosis were invited to join the present study. Twenty patients (all males) agreed to participate (Table 1). A control group of 10 male Type 2 diabetic patients with normoalbuminuria (urinary albumin excretion rate $\leq 30$ $\mathrm{mg} / 24 \mathrm{~h},(\leq 20 \mu \mathrm{g} / \mathrm{min}))$, matched for age and diabetes duration were enrolled in the study (Table 1). Furthermore, 10 agematched healthy male subjects served as a control population. They had no history of diabetes mellitus or known renal disease and on examination were found to be normoglycaemic, normotensive, and to have a negative dipstick test for urinary albumin. All subjects included in the study were Caucasian.

Diabetic patients were regarded as suffering from Type 2 diabetes if they were treated by diet alone, or diet combined with oral hypoglycaemic agents, or if they were treated with insulin and had an onset of diabetes after the age of 40 years and a body mass index above normal ( $\geq 25 \mathrm{~kg} / \mathrm{m}^{2}$ in females, $\geq 27 \mathrm{~kg} / \mathrm{m}^{2}$ in males) at the time of diagnosis [11]. Insulin-treated lean patients (body mass index $<25 \mathrm{~kg} / \mathrm{m}^{2}$ in females, body mass index $<27 \mathrm{~kg} / \mathrm{m}^{2}$ in males) had a glucagon test performed, and Type 2 diabetes was diagnosed if a stimulated C-peptide value was equal to or above $0.60 \mathrm{pmol} / \mathrm{ml}$ [11]. Fasting blood samples for plasma C-peptide determination were obtained before and $6 \mathrm{~min}$ after an intravenous bolus injection of $1 \mathrm{mg}$ glucagon (Novo, Bagsvaerd, Denmark) as described previously [12].

All patients were fully informed before giving their consent, and the study was approved by the local ethical committee.

\section{Methods}

Patients had their usual breakfast and morning medication before the investigation. During the study all subjects were in the supine position except when voiding. Arterial blood pressure was measured on the right arm after 10 min rest. The measurements were carried out with an appropriately sized cuff $(25 \times 12 \mathrm{~cm}$ in lean subjects, $30 \times 15 \mathrm{~cm}$ in obese) using a Hawksley random zero sphygmomanometer and the sounds monitored to the nearest $2 \mathrm{~mm} \mathrm{Hg}$. Diastolic blood pressure was recorded at the disappearance of the Korotkoff sounds (phase V). Haemoglobin $\mathrm{A}_{1 \mathfrak{c}}$ concentration (normal range 4.1-6.1\%) was measured by an isoelectric focusing method [13]. Serum creatinine concentration was assayed by a buffered kinetic Jaffe method (MA-kit 10; Roche, Basel, Switzerland) [14]. Ophthalmoscopy through dilated pupils was carried out in all diabetic subjects. Body mass index was calculated as; (body weight in

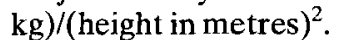

All clearance studies were carried out between 09.00 and 13.00 hours. To promote diuresis $200 \mathrm{ml}$ of tap water was given orally every hour during the clearance period. The glomerular filtration rate was measured after a single intravenous injection of $3.7 \mathrm{Mbq}$ chromium-51 labelled EDTA by determining the radioactivity in venous samples taken from the other arm 180 , 200,220 and $240 \mathrm{~min}$ after the injection [15].

Urine was collected during the 4-h clearance period. Urinary albumin concentration was measured in the timed urine samples with a radioimmunoassay [16], interassay coefficient of variation 
Table 2. Renal function and protein handling in Type 2 diabetic patients with and without diabetic nephropathy and in healthy subjects

\begin{tabular}{|c|c|c|c|c|}
\hline & $\begin{array}{l}\text { Type } 2 \text { with nephro- } \\
\text { pathy } \\
(n=20)\end{array}$ & $\begin{array}{l}\text { Type } 2 \text { without } \\
\text { nephropathy } \\
(n=10)\end{array}$ & $\begin{array}{l}\text { Healthy subjects } \\
(n=10)\end{array}$ & $p$-value \\
\hline $\begin{array}{l}\text { Systolic blood pressure } \\
\text { (mm Hg) }\end{array}$ & $164 \pm 21$ & $145 \pm 20$ & $133 \pm 19$ & $<0.05^{\mathrm{c}},<0.005^{\mathrm{d}}$ \\
\hline $\begin{array}{l}\text { Diastolic blood pressure }^{a} \\
(\mathrm{~mm} \mathrm{Hg})\end{array}$ & $92 \pm 7$ & $90 \pm 10$ & $79 \pm 8$ & $<0.005^{\text {d. e }}$ \\
\hline $\begin{array}{l}\text { Serum creatinine } \mathrm{a}^{\mathrm{a}} \\
(\mu \mathrm{mol} / \mathrm{l})\end{array}$ & $125 \pm 61$ & $70 \pm 11$ & $80 \pm 6$ & $<0.005^{c, d},<0.05^{e}$ \\
\hline $\begin{array}{l}\text { Glomerular filtration rate } \\
\left(\mathrm{ml} \cdot \min ^{-1} \cdot 1.73 \mathrm{~m}^{-2}\right)\end{array}$ & $\begin{array}{l}59 \\
(27-146)\end{array}$ & $\begin{array}{l}105 \\
(82-134)\end{array}$ & $\begin{array}{l}99 \\
(74-110)\end{array}$ & $<0.005^{\mathrm{c}},<0.05^{\mathrm{d}}$ \\
\hline $\begin{array}{l}\text { Urine albumin } \\
(\mu \mathrm{g} / \mathrm{min})\end{array}$ & $\begin{array}{l}1185 \\
(172-6027)\end{array}$ & $\begin{array}{l}10 \\
(1-49)\end{array}$ & $\begin{array}{l}9 \\
(2-14)\end{array}$ & $<0.001^{\mathrm{c}, \mathrm{d}}$ \\
\hline $\begin{array}{l}\text { Oalbumin } \\
\left(10^{-6}\right)\end{array}$ & $\begin{array}{l}659 \\
(42-4355)\end{array}$ & $\begin{array}{l}2.6 \\
(0.2-14.2)\end{array}$ & $\begin{array}{l}2.3 \\
(0.4-4.2)\end{array}$ & $<0.001^{c, d}$ \\
\hline $\begin{array}{l}\text { Urine } \operatorname{IgG}^{b} \\
(\mu \mathrm{g} / \mathrm{min})\end{array}$ & $\begin{array}{l}64.2 \\
(5.2-926)\end{array}$ & $\begin{array}{l}2.2 \\
(0.2-4.3)\end{array}$ & $\begin{array}{l}2.3 \\
(0.2-4.3)\end{array}$ & $<0.001^{\mathrm{c} \cdot \mathrm{d}}$ \\
\hline $\begin{array}{l}\theta \mathrm{IgG} \\
\left(10^{-6}\right)\end{array}$ & $\begin{array}{l}106.0 \\
(5.9-2939.2)\end{array}$ & $\begin{array}{l}2.7 \\
(0.2-5.4)\end{array}$ & $\begin{array}{l}2.8 \\
(1.9-6.3)\end{array}$ & $<0.001^{\mathrm{c} d \mathrm{~d}}$ \\
\hline $\begin{array}{l}\text { Urine } \mathrm{IgG} 4^{\mathrm{b}} \\
(\mu \mathrm{g} / \mathrm{min})\end{array}$ & $\begin{array}{l}3.2 \\
(0.01-69)\end{array}$ & $\begin{array}{l}0.04 \\
(0.01-0.79)\end{array}$ & $\begin{array}{l}0.14 \\
(0.02-0.40)\end{array}$ & $<0.001^{\mathrm{c} . \mathrm{d}}$ \\
\hline $\begin{array}{l}\theta \mathrm{IgG} 4^{\mathrm{b}} \\
\left(10^{-6}\right)\end{array}$ & $\begin{array}{l}108 \\
(7.5-3964)\end{array}$ & $\begin{array}{l}1.8 \\
(0.2-11.9)\end{array}$ & $\begin{array}{l}2.2 \\
(0.8-5.8)\end{array}$ & $<0.001^{c, d}$ \\
\hline
\end{tabular}

${ }^{a}$ Mean $\pm \mathrm{SD},{ }^{b}$ median (range). $\theta$, fractional clearance.

${ }^{c}$ Diabetic patients with nephropathy vs diabetic patients without nephropathy, ${ }^{\circ}$ diabetic patients with nephropathy vs healthy subjects, ${ }^{\mathrm{e}}$ diabetic patients without nephropathy vs healthy subjects

was $9 \%$. Serum albumin was determined using a conventional technique. Total IgG in serum and in timed urine samples were determined with a radioimmunoassay, and IgG4 in serum and in timed urine samples were measured with an enzyme linked immunosorbent assay (ELISA) as previously described [6, 17]. Intra- and interassay coefficients of variation were below $5 \%$ and $10 \%$, respectively in all assays. In this study the detection limit of the IgG4 ELISA assay was $3 \mu \mathrm{g} / \mathrm{l}$. Three patients ( 1 with nephropathy, 2 without nephropathy) had urinary IgG4 concentrations below the detection limit. In these subjects the level of urinary $\mathrm{IgG} 4$ was defined as being equal to $3 \mu \mathrm{g} / \mathrm{l}$. The sterility of urine was checked by quantitative culture.

\section{Calculations}

The fractional protein clearances $(\theta)$ were calculated as:

urinary protein excretion

serum protein concentration $\times$ glomerular filtration rate

All clearances were corrected to a body surface area of $1.73 \mathrm{~m}^{2}$. The IgG/IgG4 selectivity index was calculated as clearance of $\mathrm{IgG} /$ clearance of IgG4. This ratio of the clearance of two plasma proteins of identical size but different charge i. e. total IgG (molecular radius $55 \AA$, isoelectric point (pI) 5.8-7.3) and IgG4 (molecular radius $55 \AA$, pI 5.5-6.0) was taken as an index of glomerular charge selectivity [6]. The IgG/albumin selectivity index was calculated as clearance of $\mathrm{IgG/clearance}$ of albumin. Albumin having a molecular radius of $36 \AA$, and a pI of 4.7-5.5 [6].

\section{Statistical analysis}

Values are given as mean \pm SD or median with range. In order to test for differences between the three groups, the KruskalWallis test of variance was used. The non-parametric rank sum test (Mann-Whitney) was used when comparisons were made between two groups. For correlation analysis, Spearman's nonparametric correlation coefficient $\left(r_{\mathrm{s}}\right)$ was calculated. A $p$-value (two-tailed) of less than 0.05 was considered statistically significant. All calculations were made with a commercially available program (Statgraphics; STSC, Rockville, Md., USA).

\section{Results}

The clinical data of the Type 2 diabetic patients and the non-diabetic subjects are given in Table 1 . The groups were well matched with regard to sex and age-distribution and the diabetic groups were well matched with respect to known diabetes duration. The patients with nephropathy had subnephrotic to nephrotic range proteinuria (Table 1).

The systolic blood pressure was higher in patients with diabetic nephropathy compared to subjects without this disease (Table 2). Diastolic blood pressure was higher in both groups of diabetic patients compared to healthy subjects. Eighty-five percent (17/20) of patients with nephropathy received one or more antihyperten- 


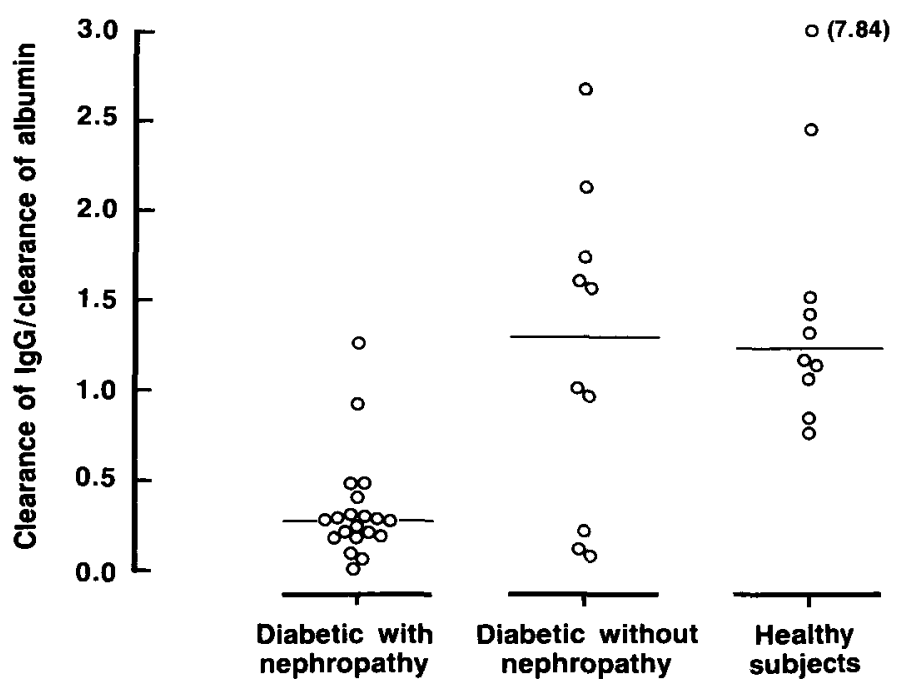

Fig. 1. Clearance of IgG/clearance of albumin in Type 2 diabetic patients with diabetic nephropathy $(n=20)$, without diabetic nephropathy $(n=10)$ and in healthy subjects $(n=10)$. The clearance of $\mathrm{IgG} /$ clearance of albumin was significantly decreased in patients with nephropathy compared to patients without nephropathy $(p<0.05)$ and compared to healthy subjects $(p<0.001)$. Medians are indicated by horizontal lines

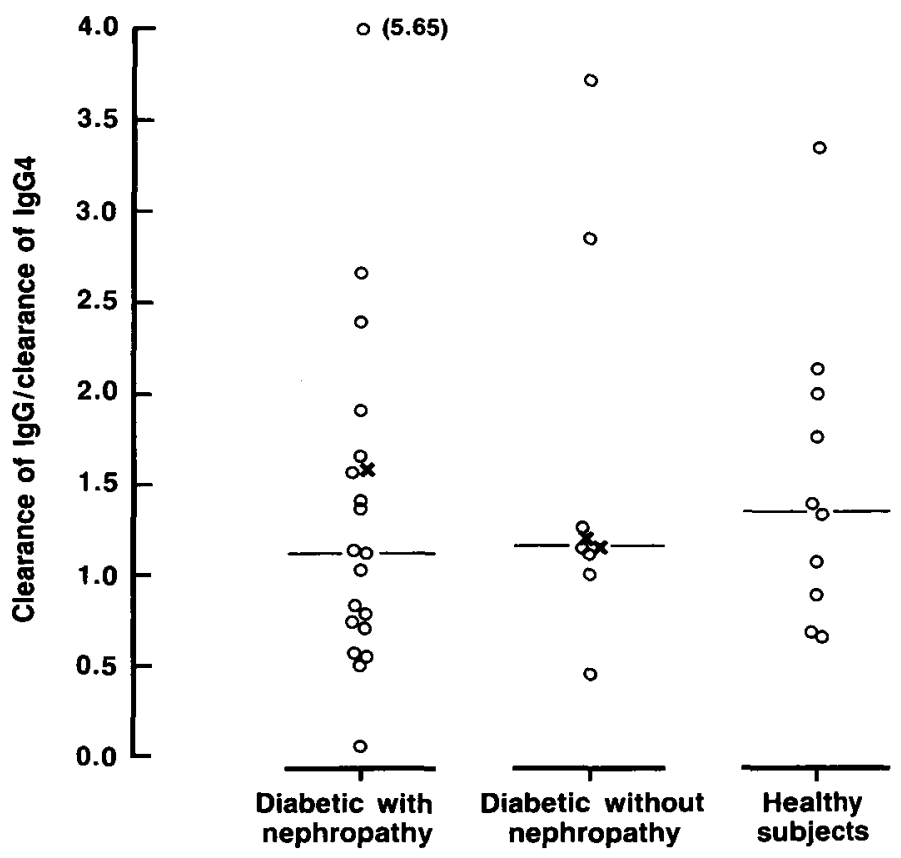

Fig. 2. Clearance of IgG/clearance of IgG4 in Type 2 diabetic patients with diabetic nephropathy $(n=20)$, without diabetic nephropathy $(n=10)$ and in healthy subjects $(n=10)$. Three diabetic patients who had urinary IgG4 concentrations below the detection limit of the $\operatorname{IgG}$ assay of $3 \mu \mathrm{g} / \mathrm{l}$ are indicated by crosses. Medians are indicated by horizontal lines

sive drugs (diuretics $n=13$, beta-blockers $n=10$, angiotensin-converting-enzyme inhibitors $n=1$, calciumantagonists $n=1$, hydralazin $n=1$ ). Fifty percent $(5 / 10)$ of the patients without nephropathy received one or two antihypertensive drugs (diuretics $n=4$, beta-blockers $n=2$, calcium-antagonists $n=1$ ) due to primary hypertension.

The glomerular filtration rate was significantly reduced in patients with nephropathy compared to diabetic patients with normoalbuminuria. In the group with nephropathy patients demonstrated a wide range of glomerular filtration rate $\left(27\right.$ to $146 \mathrm{ml} \cdot \mathrm{min}^{-1} \cdot 1.73$ $\mathrm{m}^{-2}$; Table 2). The glomerular filtration rate was comparable in patients without nephropathy and healthy subjects.

The fractional clearance of total IgG (neutral) and of IgG4 (anionic) was increased 40-50 times in patients with nephropathy compared to normoalbuminuric patients and healthy subjects (Table 2 ). These changes resulted in an $80 \%$ decrement in the IgG/albumin selectivity index; $0.27(0.01-1.26)$, (Fig. $1, p<0.05)$ compared to diabetic patients without nephropathy; 1.29 (0.07-2.67). The IgG/IgG4 selectivity index was, however not significantly different; $1.12(0.06-5.65)$ vs 1.16 $(0.45-3.72)$ in patients with and without nephropathy, respectively (Fig. 2). The albumin, IgG and IgG4 data, on which the selectivity indices are based, are depicted in Table 3. An inverse correlation was observed between the glomerular filtration rate and the fractional albumin clearance $\left(r_{\mathrm{s}}=-0.50, p<0.05\right)$ in the patients with nephropathy. A similar trend towards an inverse correlation between the glomerular filtration rate and the fractional clearance of $\operatorname{IgG}\left(r_{\mathrm{s}}=-0.37, p=0.11\right)$ and the fractional clearance of $\operatorname{IgG} 4 \quad\left(r_{\mathrm{s}}=-0.42\right.$, $p=0.07$ ) was also observed in the group with nephropathy. The glomerular filtration rate showed no correlation with the IgG/albumin selectivity index $\left(r_{s}=0.14\right.$, $p=0.55)$ or the IgG/IgG4 selectivity index $\left(r_{\mathrm{s}}=0.16\right.$, $p=0.47$ ) in the group with nephropathy. Since the group of patients with nephropathy demonstrated a wide range of glomerular filtration rate these patients were divided into quartiles based on their glomerular filtration rate. The IgG/albumin selectivity index was comparable in all four range groups of glomerular filtration rate, being $0.28(0.10-1.26)$ in the group with the highest glomerular filtration rate $(95$ to $146 \mathrm{ml}$. $\left.\min ^{-1} \cdot 1.73 \mathrm{~m}^{-2}\right)$ vs $0.26(0.05-0.41)$ in the group with the most reduced glomerular filtration rate (27 to $45 \mathrm{ml} \cdot \mathrm{min}^{-1} \cdot 1.73 \mathrm{~m}^{-2}$ ). A significant correlation between fractional albumin and fractional IgG clearances was found in the patients with nephropathy $\left(r_{\mathrm{s}}=0.79\right.$, $p<0.001)$. The systolic blood pressure was positively correlated with the fractional albumin clearance $\left(r_{\mathrm{s}}=0.46, p<0.05\right)$, and the fractional clearance of IgG and $\operatorname{IgG} 4\left(r_{\mathrm{s}}=0.45, p<0.05\right)$.

In patients without nephropathy the fractional albumin clearance was comparable to that observed in healthy subjects (Table 2). One patient without nephropathy was found to have slightly elevated urinary albumin excretion rate (i.e. above $20 \mu \mathrm{g} / \mathrm{min}$ ) during the clearance study period. This patient had urinary albumin excretion rate in the normal range before entering into the study and in three consecutive 24-h urine 
Table 3. Serum and urine albumin, IgG, and IgG4 concentrations in Type 2 diabetic patients with and without diabetic nephropathy and in healthy subjects

\begin{tabular}{|c|c|c|c|c|}
\hline & $\begin{array}{l}\text { Type } 2 \text { with nephro- } \\
\text { pathy } \\
(n=20)\end{array}$ & $\begin{array}{l}\text { Type } 2 \text { without } \\
\text { nephropathy } \\
(n=10)\end{array}$ & $\begin{array}{l}\text { Healthy subjects } \\
(n=10)\end{array}$ & $p$-value \\
\hline $\begin{array}{l}\text { Serum albumin } \\
(\mathrm{g} / \mathrm{l})\end{array}$ & $\begin{array}{l}35.0 \\
(19.8-40.6)\end{array}$ & $\begin{array}{l}40.8 \\
(39.0-45.1)\end{array}$ & $\begin{array}{l}36.3 \\
(27.5-43.1)\end{array}$ & $<0.005^{\mathrm{a}}$ \\
\hline $\begin{array}{l}\text { Serum IgG } \\
(\mathrm{g} / \mathrm{l})\end{array}$ & $\begin{array}{l}10.0 \\
(3.0-14.3)\end{array}$ & $\begin{array}{l}8.8 \\
(5.8-10.9)\end{array}$ & $\begin{array}{l}8.7 \\
(4.5-11.3)\end{array}$ & NS \\
\hline $\begin{array}{l}\text { Serum IgG4 } \\
(\mathrm{g} / \mathrm{l})\end{array}$ & $\begin{array}{l}0.65 \\
(0.006-4.06)\end{array}$ & $\begin{array}{l}0.39 \\
(0.14-1.44)\end{array}$ & $\begin{array}{l}0.55 \\
(0.21-1.67)\end{array}$ & NS \\
\hline $\begin{array}{l}\text { Urine albumin } \\
(\mathrm{mg} / \mathrm{l})\end{array}$ & $\begin{array}{l}569 \\
(47-3630)\end{array}$ & $\begin{array}{l}4.0 \\
(0.1-9.5)\end{array}$ & $\begin{array}{l}2.4 \\
(0.5-6.9)\end{array}$ & $<0.001^{\mathrm{a}, \mathrm{b}}$ \\
\hline $\begin{array}{l}\text { Urine IgG } \\
(\mathrm{mg} / \mathrm{l})\end{array}$ & $\begin{array}{l}20.90 \\
(4.55-511)\end{array}$ & $\begin{array}{l}0.90 \\
(0.05-2.05)\end{array}$ & $\begin{array}{l}0.72 \\
(0.25-1.39)\end{array}$ & $<0.001^{a . b}$ \\
\hline $\begin{array}{l}\text { Urine IgG4 } \\
(\mathrm{mg} / \mathrm{l})\end{array}$ & $\begin{array}{l}1.27 \\
(0.003-27.80)\end{array}$ & $\begin{array}{l}0.02 \\
(0.003-0.38)\end{array}$ & $\begin{array}{l}0.05 \\
(0.007-0.10)\end{array}$ & $<0.001^{\mathrm{a}, \mathrm{b}}$ \\
\hline $\begin{array}{l}\text { Clearance of IgG/clearance } \\
\text { of albumin }\end{array}$ & $\begin{array}{l}0.27 \\
(0.01-1.26)\end{array}$ & $\begin{array}{l}1.29 \\
(0.07-2.67)\end{array}$ & $\begin{array}{l}1.23 \\
(0.76-7.84)\end{array}$ & $<0.03^{\mathrm{a}},<0.001^{\mathrm{b}}$ \\
\hline $\begin{array}{l}\text { Clearance of IgG/clearance } \\
\text { of IgG4 }\end{array}$ & $\begin{array}{l}1.12 \\
(0.06-5.65)\end{array}$ & $\begin{array}{l}1.16 \\
(0.45-3.72)\end{array}$ & $\begin{array}{l}1.35 \\
(0.65-3.34)\end{array}$ & NS \\
\hline
\end{tabular}

Values are median (range).

a Diabetic patients with nephropathy vs diabetic patients without

collected the month following the day of investigation. The fractional clearance of IgG and of IgG4 was similar to that of the non-diabetic subjects. Since the fractional albumin clearance and the fractional IgG clearance were unchanged, the IgG/albumin selectivity index was comparable to the non-diabetic subjects; 1.29 (0.07$2.67)$ vs 1.23 (0.76-7.84), (Fig. 1). The IgG/IgG4 selectivity index was not significantly different being: 1.16 $(0.45-3.72)$ and $1.35(0.65-3.34)$ in patients without nephropathy and healthy subjects, respectively (Fig. 2). Also in this group of patients without nephropathy a significant correlation between fractional albumin and fractional $\operatorname{IgG}$ clearances was seen $\left(r_{\mathrm{s}}=0.90\right.$, $p<0.001$ ). Arterial blood pressure showed no correlations with the fractional protein clearances.

\section{Discussion}

Our cross-sectional study of diabetic nephropathy in Type 2 diabetic patients with subnephrotic and nephrotic range proteinuria revealed an increased fractional clearance of IgG and of IgG4 with an unchanged IgG/IgG4 selectivity index and a reduced IgG/albumin selectivity index. Since the causes of proteinuria are heterogenous in Type 2 diabetic patients we only enrolled patients with biopsy proven diabetic glomerulosclerosis [10].

The present finding of an increased fractional clearance of IgG together with a reduced IgG/albumin selectivity index in Type 2 diabetic patients with diabetic nephropathy is in agreement with the findings in Type 1 nephropathy, ${ }^{\mathrm{b}}$ diabetic patients with nephropathy vs healthy subjects

diabetic patients with clinical nephropathy $[6,8,18,19]$. However, the finding of a negative correlation between the IgG/albumin selectivity index and glomerular filtration rate in proteinuric Type 1 diabetic patients with normal to severely reduced kidney function (i.e. glomerular filtration rate below $10 \mathrm{ml} \cdot \mathrm{min}^{-1} \cdot 1.73 \mathrm{~m}^{-2}$ ), reported by Viberti et al. [8] could not be demonstrated in our patients with nephropathy (glomerular filtration rate: 27 to $146 \mathrm{ml} \cdot \mathrm{min}^{-1} \cdot 1.73 \mathrm{~m}^{-2}$ ). The glomerular filtration rate showed, however, an inverse correlation with fractional albumin clearance and a tendency towards an inverse correlation with the fractional clearance of IgG.

We observed an almost proportional increase in IgG and IgG4 clearance in patients with nephropathy, resulting in an IgG/IgG4 selectivity index which was comparable to that observed in patients without nephropathy and in healthy subjects. The present study demonstrated, however, a wide range in the IgG/IgG4 selectivity index in all three groups. A high inter-individual coefficient of variation in the $\mathrm{IgG} / \mathrm{IgG} 4$ selectivity index has also been reported in other studies $[6,20]$. The IgG/IgG4 ratio has been found to be reduced in Type 1 diabetic patients with nephropathy $[6,7]$. Furthermore, Nakamura and Myers [5] found that the fractional clearance of the more anionic species of albumin and of IgG exceeded that of the less anionic species in both mildly and heavily proteinuric Type 1 diabetic patients. These findings can only partly be explained by the recent demonstration of loss of anionic sites in the glomerular basement membrane, which only occurs when clinical proteinuria and more advanced morpho- 
logical manifestations of diabetic nephropathy are present in Type 1 diabetes [21].

To describe the charge selective properties of the glomerular barrier, the IgG/IgG4 selectivity index represents one of the best available methods in a clinical setting, due to the resemblance of structure and size between IgG and IgG4. The major disadvantage of the $\mathrm{IgG} / \mathrm{IgG} 4$ and the IgG/albumin selectivity indices is that the proteins are reabsorbed in the tubules, $(90 \%$ under normal conditions [22]), causing the index to reflect the composite action of glomerular and tubular handling. Other sources of error are local production of IgG (e.g. prostate, seminal vesicle) and low grade urinary tract infection.

Neutral dextran clearance studies in Type 1 diabetic patients have demonstrated that loss of barrier size selectivity is the main cause of proteinuria in patients with advanced stages of nephropathy [4, 5, 7, 23], whereas in the early stages of nephropathy and in patients with microalbuminuria the cause of proteinuria is mainly due to loss of barrier charge selectivity $[6,7,18$ 20]. In Pima Indians with duration of Type 2 diabetes less than 3 years and slightly increased urinary albumin-to-creatinine ratio, fractional clearance of dextran of broad size (48-60 $\AA$ ) was significantly elevated compared to non-diabetic control subjects, suggesting a defect in barrier size selectivity in Type 2 diabetes of recent onset [24]. At present, no studies on dextran clearances in albuminuric Type 2 diabetic patients with diabetic glomerulosclerosis are available.

The present demonstration of a fall in the IgG/ albumin selectivity index is not specific for diabetic glomerulopathy since this phenomenon occurs in most other non-diabetic glomerulopathies [5]. Together with a proportional rise in the clearance of $\mathrm{IgG}$ and $\mathrm{IgG} 4$, and an unaltered IgG/IgG4 selectivity index, these observations suggest that a loss of barrier size selectivity is the major cause of proteinuria in our patients. To analyse the size-selective properties of the glomerular barrier, Deen and co-workers [25] have described a theoretical model of solute transport through the glomerular capillary wall. In this model, the major portion of the capillary wall is assumed to be perforated by restrictive pores of identical radius, which differs little between healthy subjects and patients with diabetic glomerular disease, approximating $56 \AA$. In addition, a minor portion of the capillary wall is perforated by large non-discriminatory pores, and behaves in effect as a parallel "shunt pathway" through the filtration barrier. According to the theoretical "isoporous plus shunt" model [25] applied in studies dealing with Type 1 diabetes $[4,5,18,23]$ the radius of the pores in the shunt is so large that they do not discriminate among dextran molecules of up to $60 \AA$. Since the molecular radius of IgG is $55 \AA$, a value equal to that estimated of the restrictive pores of the glomerular membrane, it seems likely that this large protein passes through the glomerular capillary wall via the "shunt pathway" exclusively. Tomlanovich and co-workers [4] found a positive correlation between fractional clearances of IgG and of albumin and the fraction of filtrate volume calculated to permeate the shunt pathway. Yet another explanation for the disproportionate clearance of albumin and of IgG's could be due to the fact that the tubular reabsorption of negatively charged proteins at least in the rat is restricted, favouring their excretion compared to neutral or positively charged proteins [26, 27]. However, if this should be the only explanation, one would expect the IgG/IgG4 selectivity index to be below 1 . In our study the median value of the $\mathrm{IgG} / \mathrm{IgG} 4$ selectivity index was above 1 .

Besides being determined by the size and charge selectivity of the glomerular capillary wall, the filtration of proteins across the glomerular capillary barrier is determined by haemodynamic forces [28]. In patients with Type 1 diabetes, systemic hypertension has been shown to enhance the development of diabetic nephropathy, while effective antihypertensive treatment reduces albuminuria and diminishes the rate of decline in glomerular filtration rate $[29,30]$. Systemic hypertension is frequent in Type 2 diabetic patients with elevated urinary albumin excretion [9]. In the present study the arterial blood pressure was elevated in patients with diabetic nephropathy, despite the fact that $85 \%$ received antihypertensive therapy. We also found a positive correlation between the systolic blood pressure and the clearance of all three proteins in these patients. We have recently demonstrated a significant correlation between systolic blood pressure and the ensuing rate of decline in glomerular filtration rate in Type 2 diabetic patients with diabetic nephropathy [31]. Since impaired autoregulation of glomerular filtration rate is frequently present in diabetic nephropathy, systemic hypertension will induce hyperperfusion and glomerular hypertension [32]. Consequently, we suggest that hypertension plays an important role in the increased excretion of albumin and IgG's observed in our study.

In conclusion, our cross-sectional study suggests that impaired barrier size selectivity, probably due to an increase in large pore area ("shunt pathway") in the glomerular capillary wall and systemic hypertension are the major pathogenetic mechanisms of proteinuria in Type 2 diabetic patients with diabetic nephropathy. A more precise evaluation of the contribution from the alterations in size- and charge-selective properties can be obtained by the use of neutral and sulphated dextrans. Unfortunately, even the application of these cumbersome renal clearance techniques are in no way ideal since they overestimate the macromolecular permeability ten-fold as compared to the more rigid Ficoll molecules [33].

Acknowledgements. The expert technical assistance of Ms U.M.Smidt is gratefully acknowledged. 


\section{References}

1. Hostetter TH (1991) Diabetic nephropathy. In: Brenner BM, Rector FC Jr (eds) The kidney. 4 th edn. Saunders, Philadelphia, pp 1695-1727

2. Hostetter TH, Rennke HG, Brenner B (1982) The case for intrarenal hypertension in the initiation and progression of diabetic and other glomerulopathies. Am J Med 72: 375-380

3. Anderson S, Brenner B (1988) Pathogenesis of diabetic glomerulopathy: hemodynamic considerations. Diabetes Metab Rev 4: 163-177

4. Tomlanovich S, Deen WM, Jones HW III, Schwartz HC, Myers B (1987) Functional nature of the glomerular injury in progressive diabetic glomerulopathy. Diabetes 36:556-565

5. Nakamura Y, Myers BD (1988) Charge selectivity of proteinuria in diabetic glomerulopathy. Diabetes 37: 1202-1211

6. Deckert T, Feldt-Rasmussen B, Djurup R, Deckert M (1988) Glomerular size and charge selectivity in insulin-dependent diabetes mellitus. Kidney Int 33: 100-106

7. Deckert T, Kofoed-Enevoldsen A, Vidal P, Nørgaard K, Andreasen HB, Feldt-Rasmussen B (1993) Size- and charge selectivity of glomerular filtration in type 1 (insulin-dependent) diabetic patients with and without albuminuria. Diabetologia 36: $244-251$

8. Viberti GC, Mackintosh D, Keen H (1983) Determinants of the penetration of proteins through the glomerular barrier in insulin-dependent diabetes mellitus. Diabetes 32 [Suppl 2]: 92-95

9. Gall M-A, Rossing P, Skøtt P et al. (1991) The prevalence of micro- and macroalbuminuria, arterial hypertension, retinopathy and large vessel disease in european type 2 (non-insulin-dependent) diabetic patients. Diabetologia 34: 655-661

10. Parving H-H, Gall M-A, Skøtt P et al. (1992) Prevalence and causes of albuminuria in non-insulin-dependent diabetic patients. Kidney Int 41:758-762

11. Hother-Nielsen O, Faber O, Sørensen NS, Beck-Nielsen H (1988) Classification of newly diagnosed diabetic patients as insulin-requiring or non-insulin-requiring based on clinical and biochemical variables. Diabetes Care 11: 531-537

12. Faber OK, Binder C (1977) C-peptide response to glucagon: a test for the residual $\beta$-cell function in diabetes mellitus. Diabetes 26: 605-610

13. Mortensen HB (1980) Quantitative determination of hemoglobin $A_{1 c}$ by thinlayer isoelectric focusing. J Chromatogr 182: $325-333$

14. Ullmann R, Bonitz K (1976) Vollmechanisierte kinetische Messung von Kreatinin. Medizinische Laboratorium 29: $137-145$

15. Brøchner-Mortensen J, Giese J, Rossing N (1969) Renal inulin clearance versus total plasma clearance of $51 \mathrm{Cr}$ EDTA. Scand J Clin Invest 26: 5-11

16. Christensen C, Ørskov C (1984) Rapid screening PEG radioimmunoassay for quantitation of pathological microalbuminuria. Diabetic Nephropathy 3: 92-94

17. Fomsgaard A, Feldt-Rasmussen B, Deckert M, Dinesen B (1987) Micro-ELISA for the quantitation of human urinary IgG. Scand J Clin Lab Invest 47: 195-198
18. Scandling JD, Myers B (1992) Glomerular size-selectivity and microalbuminuria in early diabetic glomerular disease. Kidney Int 41: 840-846

19. Pietravalle P, Morano S, Christina G et al. (1991) Charge selectivity of proteinuria in type 1 diabetes explored by Ig subclass clearance. Diabetes 40: 1685-1690

20. Bangstad HJ, Kofoed-Enevoldsen A, Dahl-Jørgensen K, Hansen KF (1992) Glomerular charge selectivity and the influence of improved blood glucose control in type 1 (insulindependent) diabetic patients with microalbuminuria. Diabetologia 35: 1165-1169

21. Vernier RL, Steffes MW, Sisson-Ross S, Mauer SM (1992) Heparan sulfate proteoglycan in the glomerular basement membrane in type 1 diabetes mellitus. Kidney Int 41: 10701080

22. Mogensen CE, Sølling K (1977) Studies on renal tubular protein reabsorption: partial and near complete inhibition by certain amino acids. Scand J Clin Lab Invest 37: 477-486

23. Friedman S, Jones HW III, Golbetz HV, Lee JA, Little HL, Myers BD (1983) Mechanisms of proteinuria in diabetic nephropathy II. A study of the size-selective glomerular filtration barrier. Diabetes 32 [Suppl 2]: 40-46

24. Myers BD, Nelson RG, Williams GW et al. (1991) Glomerular function in Pima Indians with noninsulin-dependent diabetes mellitus of recent onset. J Clin Invest 88: 524-530

25. Deen WM, Bridges CR, Brenner BM, Myers BD (1985) Heteroporous model of size-selectivity: application to normal and nephrotic humans. Am J Physiol 249:F374-F389

26. Christensen EI, Carone FA, Rennke HG (1981) Effect of molecular charge on endocytic uptake of ferritin in renal proximal tubule cells. Lab Invest 44: 351-358

27. Christensen EI, Rennke HG, Carone FA (1983) Renal tubular uptake of protein: effect of molecular charge. Am J Physiol 244:F436-F441

28. Deen WM, Satvat B (1981) Determinants of the glomerular filtration of proteins. Am J Physiol 214:F162-F170

29. Parving H-H, Smidt UM, Friisberg B, Bonnevie-Nielsen V, Andersen AR (1981) A prospective study of glomerular filtration rate and arterial blood pressure in insulin-dependent diabetics with diabetic nephropathy. Diabetologia 20: 457461

30. Mogensen CE (1982) Long-term antihypertensive treatment inhibiting progression of diabetic nephropathy. BMJ 285: 685-688

31. Gall M-A, Nielsen FS, Smidt UM, Parving H-H (1993) The course of kidney function in type 2 (non-insulin-dependent) diabetic patients with nephropathy. Diabetologia 36:10711078

32. Parving H-H, Kastrup J, Smidt UM, Andersen AR, FeldtRasmussen B, Christiansen JS (1984) Impaired autoregulation of glomerular filtration rate in type 1 (insulin-dependent) diabetic patients with nephropathy. Diabetologia 27: $547-552$

33. Oliver JD, Anderson S, Troy JL, Brenner B, Deen WM (1991) Normal glomerular filtration barrier is more size-restrictive than previously determined. J Amer Soc Nephrol 2: 525 (Abstract) 